\title{
THE INFLUENCE OF RETAIL STORE IMAGE AND INDIVIDUAL FACTORS ON CONSUMER BUYING DECISIONS
}

\author{
Ioana Olariu \\ „Vasile Alecsandri” University of Bacău, Faculty of Economic Sciences \\ ioana_barin_olariu@yahoo.com
}

\begin{abstract}
In this article is examined the relationship between store image, individual factors and consumer purchase behavior. First link is made between consumer attitudes and his buying decisions. Second, the relationship between store image and consumer purchase behavior is mediated by attributes of retailer that include merchandising, store atmosphere, in-store service, accessibility, reputation, promotion, facilities and post-transaction service. This article is a theoretical approach on what is known about how people decide whether or not to buy something and then how they decide which item or items to buy and what retailer is the best choice. In the process of doing this, we will discover that the process of making a buying decision is not nearly as simply as it may seem. A good understanding about how consumers make buying decisions is very important in developing effective marketing plans. Marketers can change the design of the store interior, aisle layout, carpet and wall textures, scents, colors, shapes, and sounds experienced by the customers. Thus store image is a result of many variables which can be manipulated by the retailer to influence consumer mood and, subsequently, the buyer's behavior.
\end{abstract}

\section{Keywords}

retailer; store image; attitudes; attributes; consumer; purchase behavior

\section{JEL Classification}

M41

\section{Introduction}

A great many purchases are not based as much on what people are like as they are on simply what people want. In other words, people with different characteristics often like the exact same things. Many kind of people want some things for a variety of reasons that are not directly related to their own personal characteristics.

Good marketing planners do not take anything for granted when it comes to understanding their customers' motives, and product preferences, buying decision making. They want to know as much as possible, since any small insight can sometimes mean the difference between success and failure. This means that market planners need to understand the basic principles of consumer behavior in order to get an in-depth understanding of how people go about making a purchase.

\section{Making a purchase}

People make buying decisions in many different ways. One reason is because they buy many different types of products and services, ranging from very cheap and simple to very expensive and complex. Another reason is that there are sometimes a 
great many factors which might affect any particular purchase. Still another reason is that different people make their buying decisions in different ways, according to their own personalities and past experiences.

On the other hand, some observers feel that most people make hardly any buying decisions at all. They argue that most purchases are so simple that they do not involve much careful thought - they take place almost automatically (Olshavsky and Granbois, 1979). This is especially true for lower-priced items that most people buy frequently with hardly any thought, but it could also be true for many higher-priced items that do not require much effort or evaluation. At the other extreme are products or services that are very important to people, usually because they cost a great deal of money or have strong social implications.

A purchase involves a complex buying decision when it includes a systematic search for information, and a careful evaluation of several factors.

\section{Motivational forces affecting purchase behavior}

Every buying decision starts with a motive. The consumer may have become aware of this motive at any time before actual purchase. Motives are "all those inner striving conditions variously described as wishes, desires, needs, drives and the like. Formally, then, a motive is an inner state that energizes, activates or moves, and that directs or channels behavior toward goals" (Berelson and Steiner, 1964).

The marketing planner needs to know what the basic forces are that motivate consumers and which motives are most important for each of the company's products or services.

\section{Consumer attitudes}

Personal motives lead to a need recognition. In turn, this need starts a person through a buying decision process. The outcome of this process is a set of attitudes toward each product or brand that is evaluated. Attitudes are defined as "a person's enduring evaluations, feelings, or action tendencies toward some object or idea" (Krech, Crutchfield and Ballachey, 1962). This definition shows that attitudes encompass all three major components of the human mind: evaluations (cognitive: thought processes), feelings (affective: liking or disliking) and action tendencies (conative: motivations).

They reflect a person's overall inclinations toward a product or service offering. Once attitudes are formed, they tend to remain relatively stable over time for most types of products. This makes it important for a product to make a favorable impression on the buyer. These topics are particularly important to marketing planners, who need to develop and maintain favorable attitudes among consumers toward the company's products or services.

\section{How are attitudes formed?}

It is now generally agreed that people's attitudes toward a product or brand are based on their evaluations of the attributes of that product, for example, quality, durability, styling, sweetness, and thickness. In this view, attitudes are formed by evaluating products or brands on the basis of their attributes. The important questions are:

- How do people decide which attributes of a product should be considered?

- How do they decide how important each attribute is to them?

- How do they evaluate each brand on each attribute?

- How do they combine these attribute evaluations into an overall evaluation of each product, so they can choose the one that is best for them? 
For the more complicated decisions many people consider the importance of all attributes, together with the amount of each attribute each product possesses, and then combine these evaluations to arrive at an overall evaluation of each product. And for very complex buying decisions, they sometimes use a combination of these approaches (Punk and Staelin, 1983, Lutz, 1981).

\section{Types of attributes}

There are several ways in which products can be described in terms of their attributes. It is useful to think of three major types of product or service attributes (Myers and Shocker, 1981):

Benefits represent what the product will do for the user, what needs or objectives it helps meet.

Product characteristics are the physical properties of the product.

Imagery refers to how the product represents the user to other people and tells what type of person the user is.

All these types of attributes are important to at least some extent in nearly every consumer product or service.

\section{Attitudes and behavior}

Behind all this interest in attitudes lies one very important assumption - that attitudes lead directly to behavior. The market planner feels that if the company can create favorable attitudes toward its product or service, these attitudes will sooner or later be reflected in purchase of its brand.

Each market planner needs to determine to what extent favorable attitudes lead directly to purchase for each company's product and to what extent other factors are also important. Strategic marketing plans designed to improve people's attitudes toward a product will emphasize different things than those designed to accomplish other objectives, such as simply making people aware that the product exists, telling them how and where to get it, or opening up many new distribution outlets so they can more easily obtain the item.

\section{Consumer behavior and store image The store image}

Many specialists have focused their attention and efforts to operationalize a fundamental concept that characterizes consumer behavior - store image. This can be defined as a set of attitudes formed through evaluation by the consumer, of the most important attributes which characterize the store. Jay D. Lindquist, summarizing the views of 26 researchers in literature, managed to set up a profile of store image, given by the following new attributes rated as important:

Store offer. For its characterization are considered five attributes: quality, diversity of product range, fashion, guarantees, and price.

Services (before, during and after sales) To characterize them, are taken into account: diversity of services in general, services provided by the sales staff, the presence of self-service, the easiness of returning bought goods, the quality of service delivery, credit policies.

Customer characterized by the following attributes: social class to which he belongs, matching self-image and store staff.

Physical features, including: the existence of elevators, lighting, air conditioning, toilets existence, interior architecture, carpets, equipment for products display.

The level of access that is characterized by three factors: the degree of access, location and parking possibilities. 
Ambiance inside the store, namely the extent which meets the visitors' expectations.

Post transaction satisfaction generated by buying the product.

Promotion, which groups: sales promotion, advertising, products display, promotional stamps, symbols, colors etc.

Institutional factors, including store design, store reputation and confidence they enjoy among consumers.

\section{Shoppers and store image}

G.P. Stone proposed a classification of retail buyers according to their attitude towards stores. Following research undertaken, this author has identified four types of buyers:

Economic buyer, characterized in that it has formed his strong attitudes on prices, quality and supply sorts, being oriented towards efficient buying;

Custom buyer who feels the need to develop strong personal relationships with shop workers to gain special recognition on their part;

Ethical buyer who has formed strong attitudes towards small independent traders and unfavorable attitudes regarding retail chains;

Listless buyer who considers shopping boring and a waste of time.

\section{The decision making process of choosing a store}

As is well known in the theory of consumer behavior, a central place in most of the models created by specialists is occupied by explaining the buying decision process of a product or service. In retail marketing, the product, in its broadest sense, it is a store, restaurant or other retail unit. Kent B. Monroe and Joseph B. Guiltinam developed a model for choosing a store that is based on directional flows of influence over the buyer in the situation of taking a decision. The backbone of the model consists of four sections of baseline variables: reviews and general prospecting activities and information; strategies for substantiating the budget and planning the shopping; the importance of store attributes in process of informing the purchaser and perception of store attributes that influence its choice.

The two specialists have designed a preliminary model, suggesting the direction and meaning of each influence for all considered variables. Essentially, the model is dependent by the fundamental variable that is the buyer attitude towards the store in question. In its turn, it is considered to be dependent by the importance of store attributes and how they are perceived by the buyer, which is the global image.

Information and prospecting activities are estimated to have a direct influence on the importance of store attributes and on how they are perceived by the buyer. When the product of the last two is the largest of all considered variants, the retailer will be selected.

The starting point of the model is to consider the characteristics of the buyer (economic, demographic, personality, lifestyle, etc.) and describe how they influence his general views and activities related to the purchase. In their turn, these views and activities lead to the formation of evaluation criteria used by the buyer in selecting the stores where they will go shopping. This evaluation is based on the retailer's most important attributes, such as location, assortment structure, level of prices, promotional means and provided services. Retailers can influence the evaluation of their stores, developing appropriate strategies in the field of advertising, aesthetics and overall appearance, etc.

Buyer's characteristics will certainly affect how it sorts the store attributes and will therefore be influenced the perception on store image (perception on the attributes and 
the set of attitudes towards the shop). The perceived images on the store will influence what store will be chosen and what types of products will be bought.

If the buyer is satisfied with that retailer which through its offer and services, amounted to his expectations, the perceived positive image will be reinforced by a feedback from purchase to opinions and attitudes. It will maintain or even increase the likelihood that in the future the buyer will choose the same store.

When the buyer has had several positive experiences in relation to a particular store, he will gradually adopt a routine behavior, eliminating or simplifying some phases usually present in a buying decision process. In other words, if the buyer is satisfied with the chosen store, he will not go through all stages of the purchase decision unless it changes some important factors.

\section{Favorite stores}

Stores are chosen for their image that is the general impression on product range, quality, value and services provided by the retailer. Selection and store design have become key elements of successful marketing.

Highlights

The availability of data regarding products can influence consumer preferences; if the information is available and easy to understand, consumers will be more willing to attend the store. Information should be available in the appropriate form.

Music has a considerable contribution to the atmosphere of the store. Slow music determines spending more time shopping and an increase of the amount spent by the client, compared with fast music. Music at a strong volume reduces time dedicated to purchases, but doesn't reduces the spent amount. The choice of music must be adapted to the store type. Music can be used to manipulate the perception on store image.

Store configuration can be changed so customers can move easily through the store and come into contact with certain products; for example placing districts bakery near the store entrances to produce pleasant odors and boosting the purchasing of the products near the cash registers.

Articles placed at eye level are sold two times better than those at lower levels.

Although the effects varies, the colors of the interior and exterior must be chosen carefully. Overall color scheme contributes to the store image.

Other important factors that influence the preferences on retailers are cleanliness, loaded shelves, product range, number of cash registers, sellers' kindness, sharing disabled, aisle layout, parking, emergency exits, free bags and organic products.

\section{Conclusions}

To buy is to express oneself under the eyes of others, and thus expose oneself to being judged. People's buying decisions are often more difficult to understand than they appear to be. The various types of products and services can be classified as to whether they are high or low in involvement or importance for most people and whether they require a complex buying decision or are bought mostly by habit. Complex buying decisions require a search for information and the processing of this information to arrive at evaluations for each alternative product or brand that might be bought.

Every purchase starts with a motive of some kind. However, the same motive can usually be satisfied by several different types of products, and conversely each product can often satisfy several different motives.

Buyers are motivated by the pleasure felt at buying and by the practicality of products; stores must approach both aspects of the customer purchase experience. 
Buyers prefer stores that have a certain image and are influenced by the physical aspects of the environment such configuration, interior design, music, smells and the form in which the information is presented. Encouraging loyalty to a store greatly boosts the sales.

\section{References}

Arms, B. (2008), Marketingul local, Editura All, București.

Berelson, B., Steiner, G.A. (1964), Human Behavior: An Inventory of Scientific Findings, Harcourt, Brace and World, New York.

Blythe, J. (2005), Managementul vânzărilor şi al clienţilor cheie, Editura Codecs, Bucureşti.

Cave, S. (2005), Comportamentul consumatorului, Grupul editorial Cosmos Viking Pinguin, București.

Cătoiu, I., Teodorescu, N. (2004), Comportamentul consumatorului, Editura Uranus, București.

Datculescu, P. (2006), Cercetarea de marketing - Cum pătrunzi în mintea consumatorului, cum măsori și cum analizezi informația, Editura Brandbuilders Grup, București.

Hammond, R. (2007), Smart retail: magazinul tău - un fenomen al vânzărilor, Editura All Educational, București.

Krech, D., Crutchfield, R.S., Ballachey, E.L., (1962), Individual in Society, McGrawHill, New York.

Myers, J.H., (1986), Marketing, McGraw-Hill, Inc.

Myers, J.H., Shocker, A.D. (1981), The Nature of Product-Related Attributes, Research in Marketing, Vol. 5, pp. 211-235.

Punk, G.N., Staelin, R. (March 1983), A Model of Consumer Information Search Behavior for New Automobiles. Journal of Consumer Research, pp. 366-380.

Olshavsky, R.W., Granbois, D.H. (September 1979), Consumer Decision MakingFact or Fiction?. Journal of Consumer Research, pp. 93-99.

Smith, R.B, Sherman, E. (1993), Effects of Store Image and Mood on Consumer Behavior: a Theoretical and Empirical Analysis, Advances in Consumer Research, Vol. 20, pp. 631, http://acrwebsite.org/volumes/7530/volumes/v20/NA-20. 